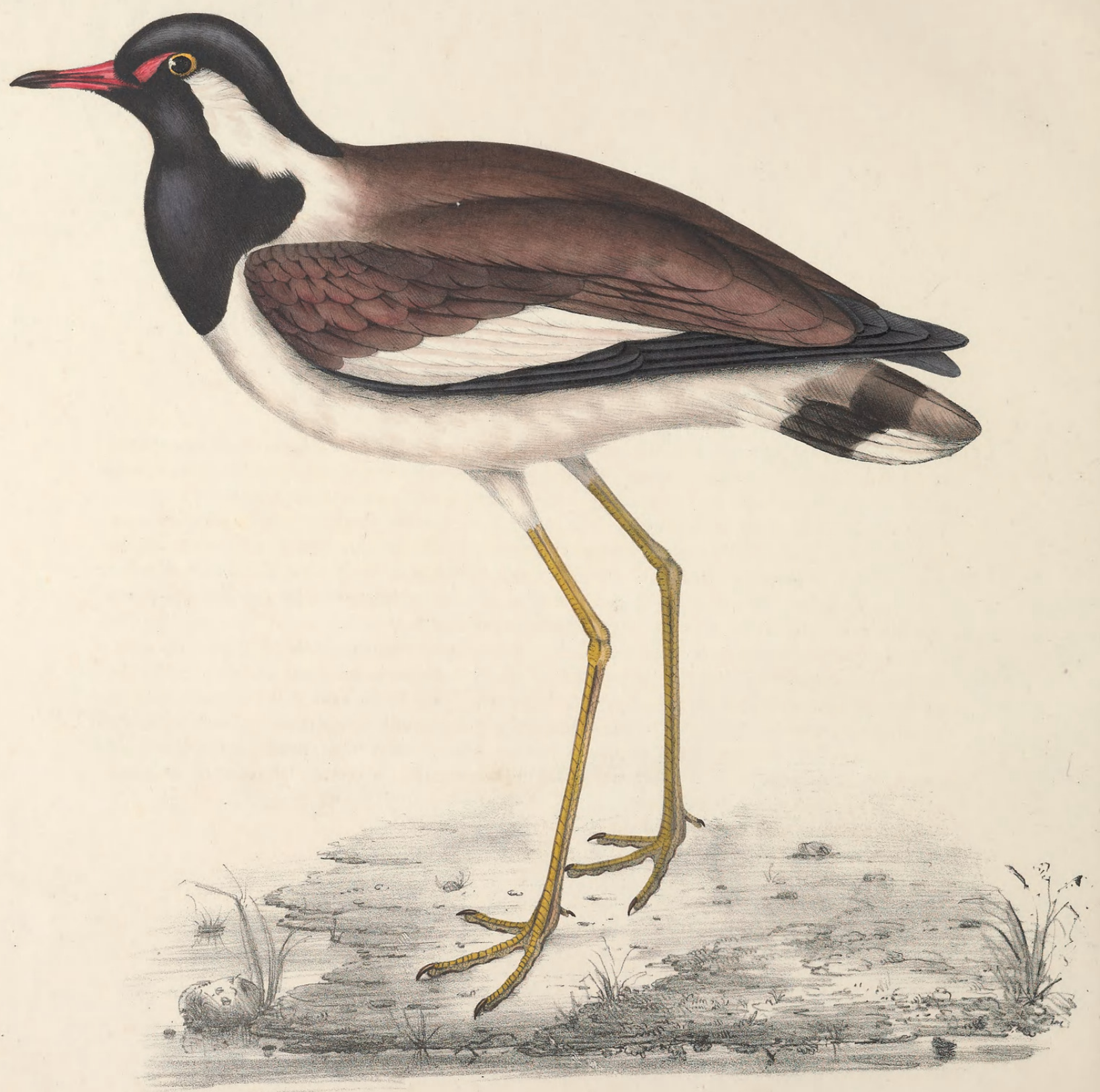

VANEIIUS GDENSIS. 


\section{TAB. LXXVIII.}

\section{VANELLUS GOENSIS.}

THIs species is not figured in the "Century" as a bird unknown to science, for we believe it to be synonymous with the Goa Lapwing of authors, but rather with a view of illustrating the only species of the genus to which it belongs that has hitherto been brought to Europe from the Himalayan mountains.

In size it is something inferior to our Lapwing, or Peewit, though the great length of its legs and more slender contour of body render it the more elegant and graceful bird of the two. The Vanellus Goensis enjoys a very widely extended locality, being met with over nearly the whole of the Eastern continent, and it has even been received from China. In all these countries, marshy and reedy spots are its most favourite places of resort, where mollusca, worms and insects, constitute its principal food.

As in all the rest of its family, there are no distinguishable marks of difference in the plumage of the sexes.

The head, occiput, back of the neck, throat, anterior aspect of the neck, and chest, are deep black; the circle of naked skin, with a process extending towards the beak, are red; the sides of the neck and whole of the under parts are white; the back and wing-coverts are ashy brown with a tinge of vinous, which especially predominates on the shoulders; outer scapularies and the lowest coverts white, forming an oblique band across the wing; quills black ; tail white, with a band of black crossing the centre ; bill red at the base, and black at the tip ; legs yellow; toes brown.

The figure is of an adult of the natural size. 


\section{$2 \mathrm{BHL}$ Biodiversity Heritage Library}

Gould, John. 1831. "Vanellus goensis [Tab. LXXVIII]." A century of birds from the Himalaya Mountains -. https://doi.org/10.5962/p.323608.

View This Item Online: https://www.biodiversitylibrary.org/item/132967

DOI: https://doi.org/10.5962/p.323608

Permalink: https://www.biodiversitylibrary.org/partpdf/323608

\section{Holding Institution}

Smithsonian Libraries

\section{Sponsored by}

Biodiversity Heritage Library

\section{Copyright \& Reuse}

Copyright Status: Public domain. The BHL considers that this work is no longer under copyright protection.

This document was created from content at the Biodiversity Heritage Library, the world's largest open access digital library for biodiversity literature and archives. Visit BHL at https://www.biodiversitylibrary.org. 